\title{
Streptococcus porci sp. nov., isolated from swine sources
}

\author{
Correspondence \\ J. F. Fernández-Garayzábal \\ garayzab@vet.ucm.es
}

\author{
A. I. Vela, ${ }^{1,2}$ M. Perez, ${ }^{1}$ L. Zamora, ${ }^{1}$ L. Palacios, ${ }^{1}$ L. Domínguez ${ }^{1}$ \\ and J. F. Fernández-Garayzábal ${ }^{1,2}$ \\ ${ }^{1}$ Centro de Vigilancia Sanitaria Veterinaria (VISAVET), Universidad Complutense, 28040 Madrid,
Spain \\ ${ }^{2}$ Departamento de Sanidad Animal, Facultad de Veterinaria, Universidad Complutense, \\ 28040 Madrid, Spain
}

\begin{abstract}
Two unidentified Gram-positive, catalase-negative, coccus-shaped organisms were recovered from pigs and subjected to a polyphasic taxonomic analysis. Based on cellular morphology and biochemical criteria, the isolates were tentatively assigned to the genus Streptococcus, although the organisms did not appear to correspond to any recognized species. Comparative 16S rRNA gene sequence studies confirmed this identification and showed that the nearest phylogenetic relatives of the unknown cocci were Streptococcus plurextorum $1956-02^{\top}$ and Streptococcus suis NCTC $10234^{\top}$ (97.9 and $96.0 \% 16 \mathrm{~S}$ rRNA gene sequence similarity, respectively). The new isolates were related most closely to $S$. suis CIP $103217^{\top}$ based on $r p o B$ gene sequence analysis ( $<8 \%$ sequence divergence). DNA-DNA pairing studies showed that one of the unidentified strains $\left(2923-03^{\mathrm{T}}\right)$ displayed DNA relatedness values of 26.6 and $27.2 \%$ with $S$. plurextorum CECT $7308^{\top}$ and S. suis NCTC $10234^{\top}$, respectively. On the basis of phenotypic and phylogenetic evidence, it is proposed that the unknown isolates from pigs be classified in the genus Streptococcus as members of Streptococcus porci sp. nov., with the type strain $2923-03^{\top}$ $\left(=\right.$ CECT $7374^{\top}=$ CCUG $\left.55896^{\top}\right)$.
\end{abstract}

The genus Streptococcus represents a large group within the low $\mathrm{G}+\mathrm{C}$ content Gram-positive bacteria. This taxon has undergone considerable expansion and revision in the past decade; currently over 65 species (Euzéby, 1997; http:// www.bacterio.net) are recognized, and novel taxa are continually being discovered within this genus (Shewmaker et al., 2007; Takada \& Hirasawa, 2007, 2008; Milinovich et al., 2008; Vela et al., 2009). Streptococci have been isolated from a wide range of environments and can be found as part of the normal flora of the skin and alimentary, respiratory and genito-urinary tracts of humans and different animals (Kilian, 1998). Some Streptococcus species have been implicated as the causes of different diseases in humans and animals, such as endometritis, respiratory infections, endocarditis, meningitis, arthritis and mastitis (Chanter, 1997; Köhler, 2007).

During routine microbiological diagnosis from different clinical specimens submitted to the Animal Health

The GenBank/EMBL/DDBJ accession numbers for the 16S rRNA and rpoB gene sequences of strain $2923-03^{\top}$ are $A M 941160$ and AM941162, respectively; those for strain 2857-03 are AM941161 and AM941163, respectively.

A supplementary figure showing an extended neighbour-joining tree based on 16S rRNA gene sequences is available with the online version of this paper.
Surveillance Centre (VISAVET) of the Universidad Complutense (Madrid, Spain), two unidentified Grampositive, coccoid organisms were recovered from the pericardium (strain $2923-03^{\mathrm{T}}$ ) and bronchial lymph nodes (strain 2857-03) of two pigs with lesions of pericarditis and pneumonia, respectively. Strains were isolated on Columbia blood agar plates (bioMérieux) incubated for $24 \mathrm{~h}$ at $37{ }^{\circ} \mathrm{C}$ under both aerobic and anaerobic [with 4$10 \% \mathrm{CO}_{2}$ using the GasPak Plus system (BBL)] conditions. On the basis of the phenotypic and phylogenetic results, a novel species of the genus Streptococcus, Streptococcus porci sp. nov., is proposed.

The new isolates were Gram-stained and assessed for the presence of catalase. Haemolytic reaction was determined on Columbia agar containing $5 \%$ defibrinated sheep blood (bioMérieux) incubated aerobically at $37{ }^{\circ} \mathrm{C}$ for 24 and $48 \mathrm{~h}$ (Facklam \& Elliot, 1995). Determination of growth at 10 and $42{ }^{\circ} \mathrm{C}$, or with $3.0,4.5$ and $6.5 \%$ added $\mathrm{NaCl}$ in brain-heart infusion broth (Difco) with the $\mathrm{pH}$ adjusted to 7.5, was performed as recommended by Facklam \& Elliot (1995). Growth in brain-heart infusion broth (Difco) was assessed at pH 9.6 (Facklam \& Elliot, 1995). Lancefield serological group reaction was determined with a commercial Slidex Strepto kit (bioMérieux) by using specific group A, B, C, D, F and G streptococcal latex-agglutinating 
antisera. The isolates were characterized biochemically by using the Rapid ID32 Strep, API 50CH and API ZYM systems (bioMérieux) according to the manufacturer's instructions. The API 50CH strips using $\mathrm{CHB}$ suspension medium were read up to 7 days incubation at $37{ }^{\circ} \mathrm{C}$. The two isolates exhibited almost-identical biochemical char- acteristics, except for the acidification of L-rhamnose, methyl $\beta$-D-xylopyranoside and pullulan (only isolate $2923-03^{\mathrm{T}}$ was positive for these tests). A detailed description of the physiological, biochemical and morphological characteristics of the isolates is given in the species description and in Table 1.

Table 1. Characteristics useful in differentiating Streptococcus porci sp. nov. from other streptococci isolated from pigs

Strains: 1 , 2923-03 ${ }^{\mathrm{T}}$ (S. porci sp. nov.); 2, S. plurextorum 1956-02 ${ }^{\mathrm{T}}$; 3, S. suis CCUG $7984^{\mathrm{T}}$; 4, S. porcinus CCUG $27628^{\mathrm{T}}$; 5 , S. dysgalactiae subsp. equisimilis CCUG $36637^{\mathrm{T}}$; 6, S. alactolyticus CCUG $27297^{\mathrm{T}}$; 7, S. bovis CCUG $34832^{\mathrm{T}}$; 8, S. orisuis CCUG 55425 ${ }^{\mathrm{T}}$; 9, S. ferus CCUG $34834^{\mathrm{T}}$; 10 , S. thoraltensis CCUG $32906^{\mathrm{T}}$; 11, S. hyointestinalis CCUG $27888^{\mathrm{T}} ; 12$, S. hyovaginalis CCUG $37866^{\mathrm{T}}$. Phenotypic data are taken from this study, from Devriese et al. (1997), Takada \& Hirasawa (2007), Vela et al. (2009) and from the CCUG database (http://www.ccug.se). +, Positive reaction; - , negative reaction; NG, non-groupable.

\begin{tabular}{|c|c|c|c|c|c|c|c|c|c|c|c|c|}
\hline Characteristic & 1 & 2 & 3 & 4 & 5 & 6 & 7 & 8 & 9 & 10 & 11 & 12 \\
\hline \multicolumn{13}{|l|}{ API Rapid ID 32 Strep } \\
\hline Hydrolysis of arginine & - & - & + & + & + & - & - & - & - & + & - & - \\
\hline$\beta$-Glucosidase & + & - & + & + & - & + & + & + & + & + & + & - \\
\hline$\beta$-Glucuronidase & - & + & + & + & + & - & - & - & - & + & - & + \\
\hline$\alpha$-Galactosidase & + & + & + & - & - & + & + & - & - & + & + & - \\
\hline Acetoin & - & - & - & + & - & + & + & - & + & + & + & + \\
\hline Glycyl-tryptophan arylamidase & + & + & + & - & - & - & - & - & - & - & - & - \\
\hline \multicolumn{13}{|l|}{ Production of acid from: } \\
\hline D-Ribose & - & - & - & + & + & - & - & - & - & + & - & + \\
\hline D-Mannitol & - & - & - & + & - & + & - & + & + & + & - & + \\
\hline D-Sorbitol & - & - & - & + & - & - & - & - & + & + & - & + \\
\hline Melibiose & + & - & - & - & - & - & + & - & - & - & - & - \\
\hline Methyl $\beta$-D-glucopyranoside & - & - & + & + & - & + & + & + & + & + & - & - \\
\hline \multicolumn{13}{|l|}{ API ZYM } \\
\hline \multicolumn{13}{|l|}{ Production of: } \\
\hline Esterase (C4) & - & - & + & - & - & + & - & - & - & - & - & + \\
\hline Esterase lipase (C8) & - & - & + & - & - & - & - & - & - & - & - & + \\
\hline Valine arylamidase & - & - & - & - & - & + & - & - & + & + & - & + \\
\hline Cystine arylamidase & - & - & - & - & + & + & - & - & - & - & - & + \\
\hline Acid phosphatase & - & + & - & + & + & - & + & - & + & + & + & + \\
\hline Naphthol-AS-BI-phosphohydrolase & - & - & - & + & + & - & - & + & - & - & - & + \\
\hline$\beta$-Galactosidase & + & + & + & - & - & - & - & - & - & - & - & + \\
\hline Cellobiose & + & - & + & + & - & + & + & + & + & + & + & + \\
\hline Inulin & - & - & + & - & - & - & + & + & - & + & - & - \\
\hline Starch & + & - & + & - & - & - & + & - & - & - & - & - \\
\hline Glycogen & + & - & + & - & - & - & + & - & - & - & - & - \\
\hline Gentiobiose & - & - & - & + & - & + & + & + & + & + & + & - \\
\hline Lancefield antigen & B & B & $\mathrm{D}$ & $\mathrm{V}$ & $\mathrm{C}$ & $\mathrm{D}$ & $\mathrm{D}$ & $\mathrm{D}$ & $\mathrm{C}$ & NG & NG & $\mathrm{NG}$ \\
\hline
\end{tabular}


A phylogenetic analysis was performed by comparative $16 \mathrm{~S}$ rRNA gene sequence analysis as described previously (Vela et al., 2002). A large, continuous fragment (approx. 1390 bases) of the 16S rRNA gene of the two isolates was obtained bidirectionally. This analysis revealed that the two isolates had the same 16S rRNA gene sequence (100\% similarity). Sequence searches of GenBank using the program FASTA (Pearson, 1994) revealed that the unknown cocci were phylogenetically related most closely to Streptococcus plurextorum $1956-02^{\mathrm{T}}$ and Streptococcus suis NCTC $10234^{\mathrm{T}}$ (97.9 and $96.0 \% 16 \mathrm{~S}$ rRNA gene sequence similarity, respectively). These sequences and those of other representative species with validly published names within the genus Streptococcus were retrieved from GenBank and aligned with the newly determined sequence by using the program DNATools (Rasmussen, 1995). Phylogenetic trees were constructed according to three different methods: the neighbour-joining algorithm (Saitou \& Nei, 1987), performed with the programs DNATools and TreeView (Page, 1996), a maximum-likelihood analysis using PHYML software (Guindon \& Gascuel, 2003) and the maximumparsimony method, carried out using the software package MEGA version 3.1 (Kumar et al., 2004). Genetic distances for the neighbour-joining and maximum-likelihood algorithms were calculated by the Kimura two-parameter method (Kimura, 1980), and close-neighbour interchange ( search level $=2$, random additions $=100)$ was applied in maximum-parsimony analysis. Stability of the groupings was estimated by bootstrap analysis (1000 replications). Phylogenetic trees obtained by using the neighbour-joining algorithm (Fig. 1; an extended version of this tree is available as Supplementary Fig. S1 in IJSEM Online) and the other two methods (data not shown) revealed a clear affiliation of the unknown cocci (as exemplified by strain $\left.2923-03^{\mathrm{T}}\right)$ to the genus Streptococcus, and placed the novel bacterium as a separate branch within this genus. It is evident from Fig. 1 that strain $2923-03^{\mathrm{T}}$ is related closely to S. plurextorum. Bootstrap-resampling analysis shows a strong association (100\%) between the unknown swine bacterium and the aforementioned species.

Additional gene sequence analyses were carried out in order to clarify the phylogenetic affinities of the two novel isolates. Partial sequences (701 bp) of the $r p o B$ gene were amplified and sequenced as described by Drancourt et al. (2004). Evolutionary distances were calculated by using the Kimura two-parameter method (Kimura, 1980) and the resulting trees were constructed by using the neighbourjoining (Saitou \& Nei, 1987), maximum-parsimony (Kumar et al., 2004) and maximum-likelihood (Guindon \& Gascuel, 2003) methods. Bootstrap values (1000 replicates) were also calculated. Strains $2923-03^{\mathrm{T}}$ and 2857-03 showed high sequence similarity $(96.6 \%)$ in their $r p o B$ gene sequences. The highest sequence similarities for these strains were with that of S. suis CIP $103217^{\mathrm{T}}$ (91.3$91.8 \%$ ). Strain $2923-03^{\mathrm{T}}$ formed a separate branch from $S$. suis and other Streptococcus species in the phylogenetic tree inferred from $r p o B$ gene sequence comparisons (Fig. 2).

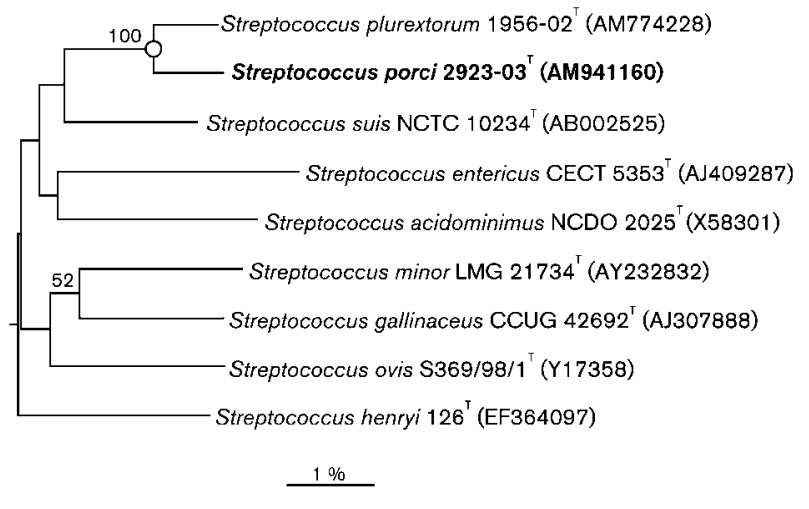

Fig. 1. Phylogenetic tree inferred from $16 \mathrm{~S}$ rRNA gene sequence comparison using the neighbour-joining method, showing the relationships of Streptococcus porci sp. nov. with other Streptococcus species. Enterococcus faecalis ATCC $19433^{\top}$ was used as an outgroup. Bootstrap values (expressed as percentages of 1000 replications) $>50 \%$ are given at branching points. $\bigcirc$ indicates that the corresponding nodes (groupings) are also obtained in both maximum-likelihood and maximum-parsimony trees. Bar, $1 \%$ sequence divergence. Supplementary Fig. S1 (available in IJSEM Online) presents a full version of the phylogenetic tree, which includes a wider sample of Streptococcus species.

DNA-DNA hybridization experiments were carried out between the two isolates (strains $2923-03^{\mathrm{T}}$ and 2857-03) and between strain $2923-03^{\mathrm{T}}$ and its nearest phylogenetic neighbours, S. plurextorum CECT $7308^{\mathrm{T}}$ and S. suis NCTC $10234^{\mathrm{T}}$. Genomic DNA was isolated by using a French pressure cell (Thermo Spectronic) and was purified by chromatography on hydroxyapatite as described by Cashion et al. (1977). DNA-DNA hybridization was carried out in $2 \times$ SSC at $68{ }^{\circ} \mathrm{C}$ by the Identification Service of the DSMZ (Braunschweig, Germany), using the method described by De Ley et al. (1970) under consideration of the modifications described by Huß et al. (1983), with a model Cary 100 Bio UV/VIS spectrophotometer equipped with a Peltier-thermostatted $6 \times 6$ multicell changer and a temperature controller with in situ temperature probe (Varian). The DNA-DNA hybridization study showed $81.7 \%$ DNA relatedness between the two new isolates, demonstrating that they are members of the same species (Wayne et al., 1987). DNA-DNA reassociation values between strain $2923-03^{\mathrm{T}}$ and $S$. plurextorum CECT $7308^{\mathrm{T}}$ and S. suis NCTC $10234^{\mathrm{T}}$ were 26.6 and $27.2 \%$, respectively, clearly confirming that the new isolates constitute a separate species (Wayne et al., 1987).

The $\mathrm{G}+\mathrm{C}$ content of the DNA of one representative isolate $\left(\right.$ strain $2923-03^{\mathrm{T}}$ ) was determined at the DSMZ by using the HPLC method of Mesbah et al. (1989). The DNA G + C content of strain $2923-03^{\mathrm{T}}$ was $41.5 \mathrm{~mol} \%$.

Based on phylogenetic and phenotypic criteria, it is clear that the unidentified catalase-negative cocci merit clas- 


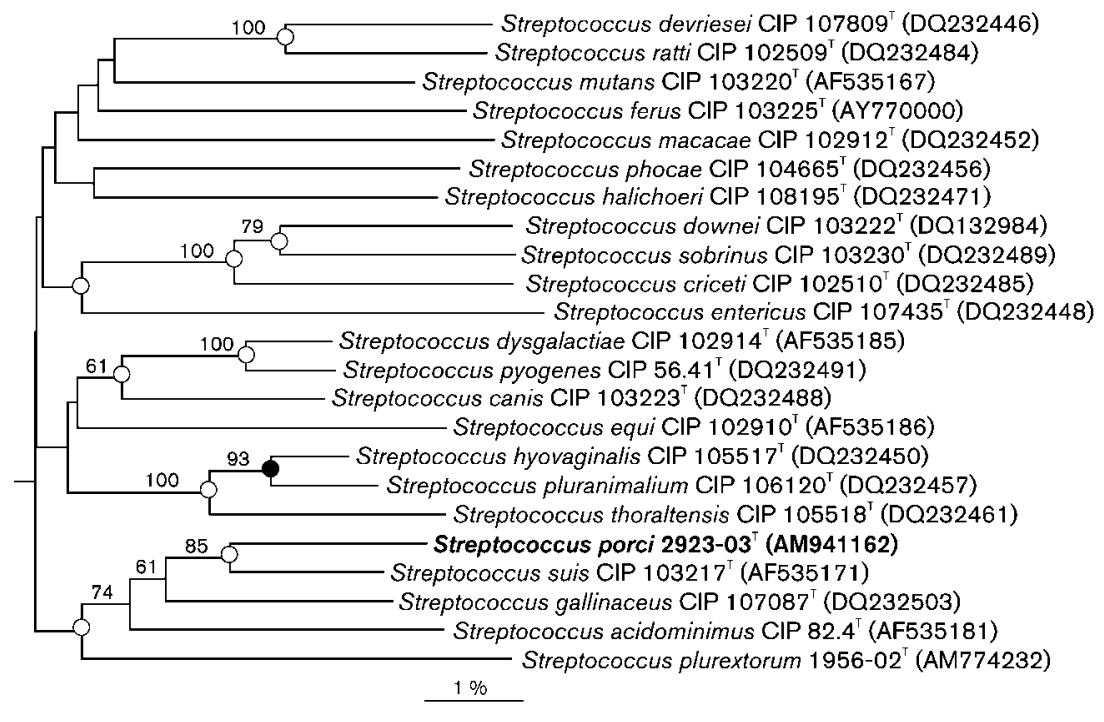

Fig. 2. Phylogenetic tree inferred from comparison of rpoB gene fragment sequences, showing the relationships of Streptococcus porci sp. nov. with other Streptococcus species. Enterococcus faecalis ATCC $19433^{\top}$ was used as an outgroup. Bootstrap values (expressed as percentages of 1000 replications) $>50 \%$ are given at branching points. indicates that the corresponding node (grouping) is also obtained in maximumparsimony trees; $\bigcirc$ indicates that the corresponding nodes (groupings) are also obtained in both maximum-likelihood and maximumparsimony trees. Bar, $1 \%$ sequence divergence. sification as members of a novel species of the genus Streptococcus, for which the name Streptococcus porci sp. nov. is proposed. The two isolates were recovered from different animals and in different farms located in different provinces of Spain. Therefore, it is very unlikely that the isolates could have any epidemiological clonality. Tests that are useful in differentiating $S$. porci from those streptococcal species that have been isolated from pigs or have clinical relevance for this animal species are shown in Table 1. Only one isolate of $S$. porci was isolated in pure culture from the heart of a pig with pericarditis, which precludes any conclusions about the possible pathogenic role for pigs of this novel species of Streptococcus.

\section{Description of Streptococcus porci sp. nov.}

Streptococcus porci (por'ci. L. gen. n. porci of a pig).

Cells are Gram-positive, non-spore-forming cocci, 0.3$0.5 \mu \mathrm{m}$ in diameter, occurring in pairs or short chains of three to eight cells. Colonies on blood agar are small, circular and non-pigmented, $0.75-1.0 \mathrm{~mm}$ in diameter and $\alpha$-haemolytic at $37^{\circ} \mathrm{C}$. Cells are facultatively anaerobic, catalase-negative and non-motile. Cells react to streptococcal group B antisera and are able to grow at $37^{\circ} \mathrm{C}$ and at $\mathrm{pH} 9.6$, but do not grow at 10 or $42{ }^{\circ} \mathrm{C}$ or in the presence of $6.5 \% \mathrm{NaCl}$. With the API 50CH and Rapid ID32 Strep kits (bioMérieux), cells are able to produce acid from Dlactose, D-glucose, D-fructose, salicin, maltose, melibiose, D-galactose, D-xylose, D-mannose, $N$-acetylglucosamine, trehalose, starch, cellobiose, arbutin, raffinose and sucrose, but not from glycerol, erythritol, D-arabinose, D-ribose, Lxylose, D-adonitol, L-arabitol, D-arabitol, gentiobiose, Dmannitol, inositol, dulcitol, melezitose, inulin, methyl $\alpha$-Dmannopyranoside, methyl $\alpha$-D-glucopyranoside, methyl $\beta$ D-glucopyranoside, L-sorbose, turanose, D-lyxose, xylitol, D-fucose, L-fucose, amygdalin, sorbitol, aesculin, 2-ketogluconate, 5-ketogluconate, cyclodextrin or tagatose. Cells are able to produce acid from glycogen and L-arabinose using the API 50CH system. The type strain produces acid from L-rhamnose, methyl $\beta$-D-xylopyranoside (API 50CH) and pullulan (Rapid ID32 Strep). $\beta$-Galactosidase, $\alpha$ glucosidase, leucine arylamidase (API ZYM), $\alpha$-galactosidase, $\beta$-glucosidase (API ZYM and Rapid ID32 Strep), alanine-phenylalanine-proline arylamidase and glycyl-tryptophan arylamidase (Rapid ID32 Strep) are detected. No activity is detected for $N$-acetyl- $\beta$-glucosaminidase, naphthol-AS-BI-phosphohydrolase, $\alpha$-mannosidase, $\alpha$ fucosidase, esterase C4, esterase lipase C8, lipase C14, valine arylamidase, cystine arylamidase, trypsin, acid phosphatase, $\alpha$-chymotrypsin (API ZYM), alkaline phosphatase, $\beta$-glucuronidase (API ZYM and Rapid ID32 Strep), $\beta$-mannosidase or pyroglutamic acid arylamidase (Rapid ID32 Strep). Arginine, hippurate and urea are not hydrolysed (Rapid ID32 Strep). Acetoin is not produced (Rapid ID32 Strep). The DNA G + C content of the type strain is $41.5 \mathrm{~mol} \%$.

The type strain, $2923-03^{\mathrm{T}} \quad\left(=\mathrm{CECT} \quad 7374^{\mathrm{T}}=\mathrm{CCUG}\right.$ $55896^{\mathrm{T}}$ ), was isolated from the heart of a pig with pericarditis. Full range of habitat is not known.

\section{Acknowledgements}

The authors thank Professor J. P. Euzéby of the Ecole Nationale Vétérinaire in Toulouse, France, for advice concerning the Latin species name, A. Casamayor for technical assistance and Juncal Fernández-Garayzábal for her assistance with the English reviewing of the manuscript.

\section{References}

Cashion, P., Holder-Franklin, M. A., McCully, J. \& Franklin, M. (1977). A rapid method for the base ratio determination of bacterial DNA. Anal Biochem 81, 461-466.

Chanter, N. (1997). Streptococci and enterococci as animal pathogens. Soc Appl Bacteriol Symp Ser 26, 100S-109S. 
De Ley, J., Cattoir, H. \& Reynaerts, A. (1970). The quantitative measurement of DNA hybridization from renaturation rates. Eur $J$ Biochem 12, 133-141.

Devriese, L. A., Pot, B., Vandamme, P., Kersters, K., Collins, M. D., Alvarez, N., Haesebrouck, F. \& Hommez, J. (1997). Streptococcus hyovaginalis sp. nov. and Streptococcus thoraltensis sp. nov., from the genital tract of sows. Int J Syst Bacteriol 47, 1073-1077.

Drancourt, M., Roux, V., Fournier, P. E. \& Raoult, D. (2004). rpoB gene sequence-based identification of aerobic Gram-positive cocci of the genera Streptococcus, Enterococcus, Gemella, Abiotrophia, and Granulicatella. J Clin Microbiol 42, 497-504.

Euzéby, J. P. (1997). List of Bacterial Names with Standing in Nomenclature: a folder available on the Internet. Int J Syst Bacteriol 47, 590-592.

Facklam, R. R. \& Elliot, J. A. (1995). Identification, classification, and clinical relevance of catalase-negative, Gram-positive cocci, excluding the streptococci and enterococci. Clin Microbiol Rev 8, 479-495.

Guindon, S. \& Gascuel, O. (2003). A simple, fast, and accurate algorithm to estimate large phylogenies by maximum likelihood. Syst Biol 52, 696-704.

Huß, V. A. R., Festl, H. \& Schleifer, K. H. (1983). Studies on the spectrophotometric determination of DNA hybridization from renaturation rates. Syst Appl Microbiol 4, 184-192.

Kilian, M. (1998). Streptococcus and Lactococcus. In Topley \& Wilson's Microbiology and Microbial Infections, vol. 2, Systematic Bacteriology, pp. 633-667. Edited by A. Balows \& B. I. Duerden. London: Arnold.

Kimura, M. (1980). A simple method for estimating evolutionary rates of base substitutions through comparative studies of nucleotide sequences. J Mol Evol 16, 111-120.

Köhler, W. (2007). The present state of species within the genera Streptococcus and Enterococcus. Int J Med Microbiol 297, 133-150.

Kumar, S., Tamura, K. \& Nei, M. (2004). MEGA3: integrated software for molecular evolutionary genetics analysis and sequence alignment. Brief Bioinform 5, 150-163.

Mesbah, M., Premachandran, U. \& Whitman, W. B. (1989). Precise measurement of the $\mathrm{G}+\mathrm{C}$ content of deoxyribonucleic acid by highperformance liquid chromatography. Int J Syst Bacteriol 39, 159-167.
Milinovich, G. J., Burrell, P. C., Pollitt, C. C., Bouvet, A. \& Trott, D. J. (2008). Streptococcus henryi sp. nov. and Streptococcus caballi sp. nov., isolated from the hindgut of horses with oligofructose-induced laminitis. Int J Syst Evol Microbiol 58, 262-266.

Page, R. D. M. (1996). TreeView: an application to display phylogenetic trees on personal computers. Comput Appl Biosci 12, 357-358.

Pearson, W. R. (1994). Using the FASTA program to search protein and DNA sequence databases. Methods Mol Biol 24, 307-331.

Rasmussen, S. W. (1995). DNA Tools, a software package for DNA sequence analysis. Copenhagen: Carlsberg Laboratory.

Saitou, N. \& Nei, M. (1987). The neighbor-joining method: a new method for reconstructing phylogenetic trees. Mol Biol Evol 4, 406425.

Shewmaker, P. L., Camus, A. C., Bailiff, T., Steigerwalt, A. G., Morey, R. E. \& Carvalho, M. S. (2007). Streptococcus ictaluri sp. nov., isolated from Channel catfish Ictalurus punctatus broodstock. Int J Syst Evol Microbiol 57, 1603-1606.

Takada, K. \& Hirasawa, M. (2007). Streptococcus orisuis sp. nov., isolated from the pig oral cavity. Int J Syst Evol Microbiol 57, 12721275.

Takada, K. \& Hirasawa, M. (2008). Streptococcus dentirousetti sp. nov., isolated from the oral cavities of bats. Int J Syst Evol Microbiol 58, $160-163$.

Vela, A. I., Fernandez, E., Lawson, P. A., Latre, M. V., Falsen, E., Dominguez, L., Collins, M. D. \& Fernandez-Garayzabal, J. F. (2002). Streptococcus entericus sp. nov., isolated from cattle intestine. Int J Syst Evol Microbiol 52, 665-669.

Vela, A. I., Casamayor, A., Sánchez del Rey, V., Dominguez, L. \& Fernández-Garayzábal, J. F. (2009). Streptococcus plurextorum sp. nov., isolated from swine. Int J Syst Evol Microbiol 59, 504-508.

Wayne, L. G., Brenner, D. J., Colwell, R. R., Grimont, P. A. D., Kandler, O., Krichevsky, M. I., Moore, L. H., Moore, W. E. C., Murray, R. G. E. \& other authors (1987). International Committee on Systematic Bacteriology. Report of the ad hoc committee on reconciliation of approaches to bacterial systematics. Int J Syst Bacteriol 37, 463-464. 